\title{
Some microbiological, chemical analysis and nitrate nitrite levels of drinking and well water samples in Afyonkarahisar
}

\author{
Mehmet ÖZDEMIR ${ }^{1}$, Belgin SIRIKEN ${ }^{2}$, Hidayet YAVUZ ${ }^{1}$, Yavuz O. BİRDANE ${ }^{1}$ \\ ${ }^{1}$ Department of Pharmacology and Toxicology, Faculty of Veterinary Medicine, Afyon Kocatepe University, 03200 Afyonkarahisar, \\ ${ }^{2}$ Deparment of Food Hygiene and Technology, Faculty of Veterinary Medicine, Ondokuz May1s University, 55139 Samsun.
}

\begin{abstract}
Summary: A total of 100 tap and 100 well water samples were collected from six municipalities and the city center in Afyonkarahisar region from January 2003 to December 2003 and analyzed for some microbiological, chemical parameters and nitrate nitrite levels. While total (TCC) and fecal (thermotolerant) coliforms (FCC), Escherichia coli isolation procedure were determined using multiple-tube fermentation technique, sulphide reducing anaerobe bacteria (SPS), enterococci (EC), Pseudomonas spp. (Ps), coagulase positive staphylococci (CPS), micrococci/staphylococci (MS) and total viable count (TVC) were used by spread plating technique. As an isolation of Salmonella spp were used two enrichment steps. The $\mathrm{pH}$ and hardness values, calcium, nitrate, nitrite, ammonia and total organic substance of water samples were also determined. Hardness of tap and well water was found to be $\geq 32^{\circ} \mathrm{F}$ in $19 \%$ and $20 \%$, respectively. Calcium concentration was found to be $\geq 100 \mathrm{mg} / \mathrm{l}$ in tap and well water samples as a range of $7 \%$ and $13 \%$, respectively. $\mathrm{pH}$ was found to be $\geq 8$ in $6 \%$ and in $7 \%$ of tap and well water samples, respectively. Ammonia did not detect in the samples. Nitrate concentrations, greater than accepted level for safe drinking-water of $45 \mathrm{mg} / 1$ (Turkish Drinking Water Regulation) were present in $48 \%$ and $78 \%$ in tap and well water samples, respectively. Nitrite was also found to be over of $38 \%$ in tap and 58\% in well water samples, respectively, according to the regulations permitting $(0.05 \mathrm{mg} / \mathrm{l})$. As a result, $15 \%$ tap and $16 \%$ well water samples for TCC and FCC, 1\% tap water for Salmonella spp., 47\% well and 39\% tap water for total organic substance, $48 \%$ tap and $78 \%$ well water samples for nitrate, $38 \%$ tap and $58 \%$ well water samples for nitrite were found to be high levels according to Turkish Food Codex.
\end{abstract}

Keywords: Chemical, microbiology, nitrate, nitrite, water.

\section{Afyonkarahisar'da içme ve kuyu sularının bazı mikrobiyolojik, kimyasal analizleri ve nitrat nitrit düzeyleri}

Özet: Ocak-Aralık 2003 döneminde Afyonkarahisar şehir merkezi ve bu ile bağlı 6 belediyeden toplam 100 adet çeşme ve 100 adet kuyu suyu örneği toplanıldı ve bazı mikrobiyolojik, kimyasal parametreler ile nitrat nitrit düzeylerini belirlemek amacıyla analiz edildi. Total (TCC) ve fekal (termotolerant) koliform (FCC), Escherichia coli izolasyonu çoklu tüp fermentasyon tekniği ile saptanırken, sülfit indirgeyen anaerob bakteri (SPS), enterokok (EC), Pseudomonas spp. (Ps), koagulaz pozitif stafilokok (CPS), mikrokok/stafilokok (MS) ve aerob mezofil genel canlı (TVC) sayılarını belirlemek amacıyla yayma plak yöntemi kullanıldı. Salmonella spp. izolasyonu amacıyla iki aşamalı zenginleştirme işlemi uygulandı. Ayrıca, suların pH değeri, sertlik düzeyi, kalsiyum, nitrat, nitrit, amonyak ve total organik madde miktarı da saptandı. Çeşme ve kuyu suları örneklerinde sertlik sırasıly \%19 ve $\% 20$ 'sinde $\geq 32^{\circ} \mathrm{F}$ olarak belirlendi. Kalsiyum konsantrasyonu çeşme sularının sırasıyla $\%$ 7'sinde ve kuyu sularının $\% 13$ 'ünde $\geq 100$ $\mathrm{mg} / \mathrm{l}$ olduğu bulundu. $\mathrm{pH}$ değeri çeşme ve kuyu suları örneklerinin sırasıyla $\% 6$ ve $\% 7$ 'sinde $\geq 8$ olduğu belirlendi. Sularda amonyak saptanamadı. Nitrat konsantrasyonu içme ve kuyu sularında sırasıyla $\% 48$ ve $\% 78$ düzeylerinde içme sularında güvenlik için kabul edilen $45 \mathrm{mg} / \mathrm{l}$ 'den (İçme Suyu Yönetmeliği) yüksekti. Nitrit ise içme sularında \%38 ve kuyu sularında \%58 oranlarında yönetmeliğin izin verdiği limitin $(0,05 \mathrm{mg} / \mathrm{l})$ üzerinde bulundu. Sonuç olarak, \%15 çeşme ve \%16 kuyu suyu örnekleri TCC ve FCC yönünden, \%1 çeşme suyu Salmonella spp. yönünden, \%47 kuyu ve \%39 çeşme suyu örnekleri total organik madde yönünden, \%48 çeşme ve $\% 78$ kuyu suyu örnekleri nitrat ve $\% 38$ çeşme ve $\% 58$ kuyu suyu örnekleri nitrit yönünden Türk Gıda Kodeksi'ne uygun olmadığı saptanıldı.

Anahtar sözcükler: Kimyasal, mikrobiyoloji, nitrat, nitrit, su.

\section{Introduction}

Providing adequate amounts of drinking water of an acceptable quality is a basic necessity and ensuring the sustainable, long-term supply of such drinking water is a national and international. Due to the interactions between exposure to enteric pathogens via poor quality water, lack of sanitation and inadequate hygiene, data resolving the waterborne component is not generally available (22). The World Health Organization estimates that about 1.1 billion people globally drink unsafe water 
and the vast majority of diarrhea disease in the world $(88 \%)$ is attributable to unsafe water, sanitation and hygiene (30). The most common form of disease from water-borne pathogens is gastrointestinal illness. However, related health outcomes are not restricted to diarrhea; they can include other illnesses such as reactive arthritis, meningitis, impairment of neurological development, and hemolytic-uremic syndrome (2). According to Center of Diseases Control (CDC) (8), during 2001-2002, a total of 65 outbreaks associated with recreational water was reported by 23 states. Toxigenic E. coli serotypes and norovirus were the most commonly identified causes $(25.0 \%$ each) of outbreaks associated with fresh water exposure (8).

Contamination of groundwater with nitrate is a global problem. The use of synthetic fertilizers is a necessary practice in the production of food and fiber to meet the growing needs of human and livestock consumption (19). However, increasing use of nitrogenbased fertilizers has raised concerns over the possible nitrate contamination of drinking water supplies within Turkey and international agricultures areas. The nitrate concentration in surface water is normally low (0-18 $\mathrm{mg} / \mathrm{l}$ ) but can reach high levels as a result of agriculture runoff, refuse dump runoff, or contamination with human or animal wastes (17). Human adverse health effects are actually associated primarily with nitrite; however, nitrate can be converted to nitrite in the body (24). The most well known are methemoglobinemia, gastric cancer, non-Hodgkin's lymphoma (15), and it is implicated in the formation of the carcinogenic nitrosamides and nitrosamines (9). The maximum allowable concentration of nitrate used for potable water varies considerable worldwide. For instance, allowable levels for nitrate in drinking water have been set at $11.3 \mathrm{mg} / \mathrm{NO}_{3}-\mathrm{N}$ by European Union Council (11), and at $10 \mathrm{mg} / 1 \mathrm{NO}_{3}-\mathrm{N}$ by the US Environmental Protection Agency (EPA) (27). Nitrite is regulated at levels of $0.03 \mathrm{mg} / 1 \mathrm{NO}_{2}-\mathrm{N}$ and 1.0 $\mathrm{mg} / \mathrm{l} \mathrm{NO} \mathrm{NO}_{2}-\mathrm{N}$ in the EU and US, respectively, while the US adds a combined standard of $10 \mathrm{mg} / \mathrm{l}$ (as nitrogen) for the sum of these two compounds (27).

Public acceptability of the degree of hardness of water may vary considerably from one community to another, depending on local conditions. In particular, consumers are likely to notice changes in hardness. The taste threshold for the calcium ions is the range of 100$300 \mathrm{mg} / \mathrm{l}$, depending on the associated anion, and the taste threshold for magnesium is lower than that for calcium. In some instances, consumers tolerate water hardness in excess of $500 \mathrm{mg} / \mathrm{l}$. Depending on the interaction of other factors, such as $\mathrm{pH}$ and alkalinity, water with hardness above approximately $200 \mathrm{mg} / \mathrm{l}$ may cause scale deposition in the treatment. On heating, hard waters form deposits of calcium carbonate scale. Soft water, with a hardness of less than $100 \mathrm{mg} / \mathrm{l}$, may, on the other hand, have a low buffering capacity and so be more corrosive for water pipes (30). Although $\mathrm{pH}$ usually has no direct impact on consumers, it is one of the most important operational water quality parameters. Careful attention top $\mathrm{pH}$ control is necessary at all stages of water treatment to ensure satisfactory water clarification and disinfection.

We could not find any report on waterborne outbreaks or chemical quality in Afyonkarahisar province. Therefore, the aim of this study was to investigate some microbiological, chemical qualities and residual nitrate nitrite levels of tap and well water samples consumed in Afyonkarahisar province, Turkey.

\section{Materials and Methods}

A total of 100 tap and 100 well water samples were collected from six municipalities and the city center in Afyonkarahisar region from January 2003 to December 2003 as part of an epidemiological study and analyzed. Bacteriological analysis of the water samples were included enumeration of total viable count, total (TCC) and fecal (thermotolerant) coliforms (FCC), coagulase positive staphylococci, micrococci/staphylococi, Pseudomonas spp., E. coli, enterococci, sulphide reducing anaerobe bacteria and Salmonella spp. The $\mathrm{pH}$ and hardness values and calcium, nitrate, nitrite, ammonia concentrations and total organic substance of water samples were also determined.

Nitrate and nitrite: Nitrate and nitrite value of water samples were performed according to Stahr (25). In summarize, the nitrates are reduced with hydrazine in the presence of copper at a $\mathrm{pH}$ of 10.2. The nitrite diazotizes sulfanilamide is coupled finally with $\mathrm{N}$-(1-naphthyl)ethylenediamine to form a red-colored complex. This color is quantities using a spectrophotometer at $520 \mathrm{~nm}$.

Chemical analysis of water samples: Hardness, calcium, ammonia and total organic substance were performed according to Turkish Standard 266 (4).

pH measurements: The $\mathrm{pH}$ of water samples was made using an electrode of $\mathrm{pH}$ meter (WTW, Inolab Level I, Germany).

Microbiological analysis of water samples: The following bacteriological enumeration procedures were performed on each of water samples. For this purpose, three different methods were used for the determination of bacteria. TCC, FCC and E. coli isolation procedure were determined using multiple-tube fermentation procedure as a Most Probable Number (MPN) technique estimate of bacterial population density $100 \mathrm{ml}$. 
Salmonella spp., were determined using two enrichment steps. The above mentioned bacteria were used by spread plating technique and reported as colony forming units (cfu) per ml.

For this purpose, a $10 \mathrm{ml}$ water sample was transferred to a sterile flask under aseptic conditions and inoculated to specific culture media (direct inoculation). Following, ten-fold serial dilutions for each sample were made in sterile peptone-salt water up to $10^{-3}$. Each of these dilutions was inoculated to specific culture media for isolation of total viable count (Standard Plate Count Agar, Oxoid CM463, Basingstoke UK) (5), micrococci/ staphylococci, coagulase positive staphylococci (Baird Parker Medium, Oxoid CM 275, Basingstoke UK), enterococci (Slanetz and Bartley Medium, Oxoid CM 377, Basingstoke UK), Pseudomonas spp. (Pseudomonase Agar Base, Oxoid CM 559, CFC Suppl. SR 103, BR 64, Basingstoke, UK), and sulphide reducing anaerobic bacteria (Perfringens Agar Base, Oxoid CM 587, Suppl. SR 93) (7). Colonies on plates were manually counted and reported in base ten logarithms of colony forming units per $\mathrm{ml}$ of sample (Log $10 \mathrm{cfu} / \mathrm{ml})$. These microorganisms were identified after isolated with Gram staining and related tests (oxidase test-Oxoid BR 64 for Pseudomonase identification, and coagulase test for coagulase positive staphylococci identification) (7).

For the isolation of coagulase positive staphylococci, up to 5 typical colonies (black or grey colonies) grown on BP Agar were selected and, transferred to tubes contained Brain Heart Infusion Broth (BHI-Oxoid CM 225 , UK). The tubes were incubated at $37^{\circ} \mathrm{C}$ for $24 \mathrm{~h}$. After the incubation, coagulase test were done (26).

Multiple-Tube fermentation technique for members of the coliform bacteria: For this purpose, 3 fermentation tubes containing inverted Durham tubes at each of $1,0.1$, $0.01 \mathrm{ml}$ samples were added contained $10 \mathrm{ml}$ Lauryl Tryptose Broth (Oxoid, CM451, Basingstoke, UK) for pre-enrichment step. The tubes were incubated at $37^{\circ} \mathrm{C}$ for 24-48 h. After incubation, a loopful of the inoculum from the each tubes with turbidity and gase production was transferred to tube contained $10 \mathrm{ml}$ Brilliant Green 2\% Bile Broth (BGBB) (Oxoid CM31, Basingstoke, UK), inverted Durham tubes and incubated at $37^{\circ} \mathrm{C}$ for 24-48 h for selective enrichment step. After incubation, the tubes with turbidity and gase production were evaluated and calculated MPN table from the number of positive BGBB tubes (MPN/100 ml) and reported TCC (12).

Fecal coliform: A loopful of the inoculum from each BGBB tubes with turbidity and gase production was transferred to tube contained $10 \mathrm{ml}$ EC Broth with MUG and inverted Durham tubes (Oxoid, CM0979, Basingstoke, UK) and tubes were incubated $44.5^{\circ} \mathrm{C}$ in water bath. Gas production with growth in an EC-MUG broth tubes were choiced and calculated MPN table (12).

Escherichia coli: Positive EC MUG tubes for fecal coliform were choiced and examined all tubes exhibiting growth for fluorescence under long-wave ultra-violet light $(366 \mathrm{~nm})$. The presence of bright blue/green fluorescence is a positive response for $E$. coli and calculated MPN table (12).

Isolation of Salmonella species: The isolation of Salmonella species was carried out in two enrichment steps. For this purpose, $25 \mathrm{ml}$ water samples were aseptically taken and transferred into sterile flasks containing $225 \mathrm{ml}$ buffered peptone water (BPW) (Oxoid CM509, Basingstoke, UK) (1), mixed and then incubated at $37^{\circ} \mathrm{C}$ for $24 \mathrm{~h}$. Following incubation, $0.1 \mathrm{ml}$ of each BPW incubate was transferred into culture containing 10 ml Rappaport Vassiliadis (RV) enrichment broth (Oxoid CM 669, Basingstoke, UK) (29) and incubated again at $43^{\circ} \mathrm{C}$ for $24 \mathrm{~h}$. The culture was then streaked onto Brilliant Green (Modified) Agar plates (Oxoid, CM 329, Suppl. SR 87, Basingstoke, UK) and incubated for up to $48 \mathrm{~h}$ at $37^{\circ} \mathrm{C}$. The agar plates suspected of containing Salmonella spp. were selected the colonies were identified by Gram staining and standard biochemical tests (Triple Sugar Iron Agar-Oxoid CM277, Lysine Iron Agar-Oxoid CM381, Urease test-Oxoid CM53 and, Simmons Citrate-Oxoid CM155, Basingstoke, UK) and then done serological test with Salmonella antiserum (O and H-Vi polyvalan antiserum, Difco 2264-47-2).

\section{Results}

The results of microbiological analyses of samples are given in Table 1 and 2. Salmonella spp. was detected in $1 \%$ tap water samples in summer season. CPS and SPS were not detected in all samples. EC and Ps were detected in $1 \%$ and $15 \%$ well water samples, respectively at level of $10^{1} \mathrm{cfu} / \mathrm{ml}$. For tap water, while EC was detected in $<10^{1} \mathrm{cfu} / \mathrm{ml}$, Ps was detected in $10^{2} \mathrm{cfu} / \mathrm{ml}$. MS was detected in 4\% tap and 3\% well water samples at level of $10^{1} \mathrm{cfu} / \mathrm{ml}$. It is found that $10 \%$ and $\% 5$ of the tap water samples were positive for TCC and FCC at levels of 0.30-110 MPN/100 ml, respectively. For well water, it is found that $15 \%$ of the samples were positive for TCC at levels of 0.30-9.30 MPN/100 ml. FCC was detected in only one sample (1\%) at level of 0.36 MPN/100 ml. E. coli was not detected in all samples.

Nitrate levels were found to be over of $48 \%$ and $78 \%$ in tap and well water samples, respectively according to Turkish Drinking Water Regulation (Table $3,4)$. Nitrite was also found to be over of $38 \%$ of tap and $58 \%$ of well water samples, respectively, according to the regulations permitting. The chemical analyses results in water samples are shown in Table 5. 
Table 1. The microbial count distribution detected in tap and well water, enterococci, Pseudomanas spp., micrococci/ staphylococci, coagulase positive staphylococci, sulphidereducing anaerobe bacteria and Salmonella spp. (per ml).

Tablo 1. Çeşme ve kuyu sularında enterekok, Pseudomonas spp., mikrokok/stafilokok, koagulaz pozitif stafilokok, sülfid indirgeyen anaerob bakteri ve salmonella türlerinin sayısal dağılımı (\% ml).

\begin{tabular}{lcccc}
\hline $\begin{array}{l}\text { Type of } \\
\text { bacteria }\end{array}$ & $\begin{array}{c}\log _{10} \mathrm{cfu} / \mathrm{ml} \\
\text { (Tap Water) } \\
\mathrm{n}=100\end{array}$ & \multicolumn{3}{c}{$\begin{array}{c}\text { Log }_{10} \mathrm{cfu} / \mathrm{ml} \\
\text { (Well Water) } \\
\mathrm{n}=100\end{array}$} \\
\hline TVC & $<1.0 \times 10^{1}$ & 39 & $<1.0 \times 10^{1}$ & 33 \\
& $10^{1}-10^{3}$ & 55 & $10^{1}-10^{3}$ & 57 \\
& $10^{3}-10^{4}$ & 5 & $10^{3}-10^{4}$ & 10 \\
& $10^{5}-10^{6}$ & 1 & - & - \\
EC & $<1.0 \times 10^{1}$ & 100 & $<1.0 \times 10^{1}$ & 99 \\
& - & - & $10^{1}-10^{2}$ & 1 \\
Ps & $<1.0 \times 10^{1}$ & 65 & $<1.0 \times 10^{1}$ & 85 \\
& $10^{1}-10^{2}$ & 34 & $10^{1}-10^{3}$ & 15 \\
MS & $10^{2}-10^{3}$ & 1 & - & - \\
& $<1.0 \times 10^{1}$ & 96 & $<1.0 \times 10^{1}$ & 97 \\
CPS & $10^{1}-10^{2}$ & 4 & $10^{1}-10^{2}$ & 3 \\
& $<1.0 \times 10^{1}$ & 100 & $<1.0 \times 10^{1}$ & 100 \\
SPS & - & - & $<1.0 \times 10^{1}$ & 100 \\
Salmonella spp. & not found & 99 & not found & 100 \\
& found & 1 & & \\
\hline
\end{tabular}

TVC: Total viable count; EC: enterococci; Ps: Pseudomonas spp.; MS: micrococci/staphylococi; CPS: Coagulase positive staphylococci; SPS: Sulphide-reducing anaerobic bacteria.

Table 2. Coliform, fecal coliform and E. coli distribution in tap and well water ( $\mathrm{n}=100$ samples $)$.

Tablo 2. Çeşme ve kuyu sularında koliform, fekal koliform ve E. coli dağılımı (n=100 örnek)

\begin{tabular}{lcccc}
\hline $\begin{array}{c}\text { Type of } \\
\text { bacteria }\end{array}$ & $\begin{array}{c}\text { MPN/100 } \\
\mathrm{ml}\end{array}$ & $\begin{array}{c}\% \\
\text { (Tap } \\
\text { water) }\end{array}$ & $\begin{array}{c}\text { MPN/100 } \\
\mathrm{ml}\end{array}$ & $\begin{array}{c}\% \\
\text { (Well } \\
\text { water) }\end{array}$ \\
\hline TCC & $<0.30$ & 90 & $<0.30$ & 85 \\
& 0.36 & 3 & 0.30 & 1 \\
& $0.74-0.92$ & 2 & 0.36 & 6 \\
& 1.50 & 2 & 0.92 & 4 \\
& $9.30-15.00$ & 2 & 2.10 & 1 \\
& $>110$ & 1 & 2.80 & 1 \\
& & & 4.30 & 1 \\
FCC & $<0.30$ & 95 & $<0.30$ & 1 \\
& $0.30-0.36$ & 2 & 0.36 & 1 \\
& 0.92 & 1 & & \\
& 1.50 & 1 & & \\
& $>110$ & 1 & - & 100 \\
E. coli & $<0.30$ & 100 & $<0.30$ & \\
\hline
\end{tabular}

TCC: Total coliform count; FCC: fecal (thermotolerant) coliform count.
Table 3. The nitrate and nitrite levels in tap water $(n=100$ samples).

Tablo 3. Çeşme sularında nitrat ve nitrit düzeyleri ( $\mathrm{n}=100$ örnek)

\begin{tabular}{ccc}
\hline \multicolumn{1}{c}{ Nitrate levels } & $\mathrm{n}(\%)$ & Min-Max \\
\hline $0-45\left(\mathrm{NO}_{3}^{-}\right) \mathrm{mg} / \mathrm{l}$ & $52(52)$ & $6.11-44.82$ \\
$46-445\left(\mathrm{NO}_{3}^{-}\right) \mathrm{mg} / \mathrm{l}$ & $48(48)$ & $45.17-162.31$ \\
\hline & & \\
Nitrite levels & & \\
\hline $0-0.05\left(\mathrm{NO}_{2}^{-}\right) \mathrm{mg} / \mathrm{l}$ & $62(62)$ & $0-0.05$ \\
$0.06-1\left(\mathrm{NO}_{2}^{-}\right) \mathrm{mg} / 1$ & $38(38)$ & $0.06-0.95$ \\
\hline
\end{tabular}

Table 4. The nitrate and nitrite levels in well water $(n=100$ samples).

Tablo 4. Kuyu sularında nitrat ve nitrit düzeyleri $(n=100$ örnek).

\begin{tabular}{lcc}
\hline \multicolumn{1}{c}{ Nitrate levels } & $\mathrm{n}(\%)$ & Min-Max \\
\hline $0-45\left(\mathrm{NO}_{3}^{-}\right) \mathrm{mg} / \mathrm{l}$ & $22(22)$ & $13.28-44.42$ \\
$46-445\left(\mathrm{NO}_{3}^{-}\right) \mathrm{mg} / 1$ & $76(76)$ & $46.83-442.83$ \\
$445->\left(\mathrm{NO}_{3}^{-}\right) \mathrm{mg} / 1$ & $2(2)$ & $460.72-470.16$ \\
\hline & & \\
Nitrite levels & & \\
\hline $0-0.05\left(\mathrm{NO}_{2}^{-}\right) \mathrm{mg} / 1$ & $42(42)$ & $0-0.05$ \\
$0.06-1\left(\mathrm{NO}_{2}^{-}\right) \mathrm{mg} / 1$ & $58(58)$ & $0.06-0.90$ \\
\hline
\end{tabular}

Table 5. $\mathrm{pH}$, hardness, calcium, total organic substance, ammonia distribution in tap and well water ( $\mathrm{n}=100$ samples). Tablo 5. Çeşme ve kuyu sularında $\mathrm{pH}$, sertlik, kalsiyum, toplam organic madde ve amonyak dağılımı (n=100 örnek).

\begin{tabular}{lcccc}
\hline & Levels & $\begin{array}{c}\text { \% (Tap } \\
\text { water) }\end{array}$ & Levels & $\begin{array}{c}\text { \% (Well } \\
\text { water) }\end{array}$ \\
\hline $\mathrm{pH}$ & $<6.0$ & 3 & $6.0-6.5$ & 1 \\
& $6.0-8$ & 91 & $6.5-8.0$ & 92 \\
& $8.0-8.5$ & 6 & $8.0-8.5$ & 7 \\
Hardness $\left({ }^{\circ} \mathrm{F}\right)$ & $6-11$ & 5 & $6-11$ & 4 \\
& $11-14$ & 6 & $11-14$ & 3 \\
& $14-29$ & 61 & $14-26$ & 48 \\
& $29-32$ & 9 & $26-32$ & 25 \\
& $32-41$ & 14 & $32-41$ & 16 \\
& $41-50$ & 5 & $\geq 50$ & 4 \\
Calcium (mg/l) & $<10$ & 1 & $10-20$ & 4 \\
& $10-40$ & 12 & $20-40$ & 12 \\
& $40-90$ & 76 & $40-100$ & 71 \\
& $90-100$ & 4 & $100-180$ & 12 \\
& $100-200$ & 6 & $\geq 180$ & 1 \\
Total Organic & $\geq 200$ & 1 & & \\
Substance (mg/l) & $1-3.5$ & 6 & $<1$ & 0 \\
Ammonia & $>3.5$ & 39 & $1-3.5$ & 53 \\
& & not & & 47 \\
& & detected & & detected \\
\hline
\end{tabular}




\section{Discussion and Conclusion}

In the present study, Salmonella spp. was detected in tap water samples in summer season. In the same municipality, there was one waterborne outbreak caused Salmonella spp. in previous summer season. So, there is still a problem in tap water and there is a health risk for consumed for human at least in this region. The current limits set by the Turkish legislation according to (3) directive effectively require a zero presence of coliforms, fecal (thermotolerans) coliforms and E. coli in a $100 \mathrm{ml}$ sample of drinking water. In this respect, a total of $15 \%$ of tap and $16 \%$ of well water samples were not suitable according to Turkish regulation for these parameters. Other study from Turkey, Hasde et al. (14) reported that they detected in $50 \% \mathrm{E}$. coli in well water, whereas, Salmonella and Shigella were not detected in well water samples ( $n=28)$. Reid et al. (23) reported that the quality of private water supplies within Aberdeenshire sampled ( 1750 samples) between 1992 and 1998 was analyzed for the presence of TCC and FCC and, the individual failure rate was $41 \%$ and $30 \%$ for TCC and FCC, respectively.

It is known that the significantly positive relationship found between the FCC indicator and the average seasonal rainfall amounts is consistent with the microbiological quality deterioration in response to rainfall (16). It was supported by Giannoulis et al. (13) study. They reported that, the seasonal variation of FCC (cfu/100 ml) between 1996 and 1999, and they concluded that there was greater consistency among failures of FCC indicators standards during autumn and winter than during spring and summer. This variability was partially explained by changes in hydrological condition.

The total viable count provides an approximately enumeration of total numbers of viable bacteria that may be yield useful information about water quality and may provide supporting data on the significance of coliform test results. The present study, TVC was detected in $6 \%$ of tap and $10 \%$ well water samples at levels of $>10^{3}$ $\mathrm{cfu} / \mathrm{ml}$. In addition to FCC, generally, the total viable count is also valuable for checking quality of finished water in a distribution system as an indicator of microbial regrowth procedures for the isolation of certain pathogenic bacteria and protozoa are presented.

Public acceptability of the degree of hardness of water may vary considerably from one community to another, depending on local conditions. In the present study, hardness of tap water was found to be $\geq 32^{\circ} \mathrm{F}$ in $19 \%$. Calcium concentration was found to be $\geq 100 \mathrm{mg} / 1$ in $6 \%$ and in $1(1 \%)$ sample was at level of $\geq 200 \mathrm{mg} / 1$. For well water, hardness was found to be $\geq 32^{\circ} \mathrm{F}$ in $20 \%$ and calcium concentration was found to be $\geq 100 \mathrm{mg} / \mathrm{l}$ in $12 \%$ and only one sample was found to be $\geq 180 \mathrm{mg} / 1$.
In the present study, $\mathrm{pH}$ value was found to be $\geq 8$ in 6 and in 7 of tap and well water samples, respectively. The optimum $\mathrm{pH}$ required will vary in different supplies according to the composition of the water and the nature of the construction materials used in the distribution system, but it is usually in the range from 6.5 to 8 . Although $\mathrm{pH}$ usually has no direct impact on consumers, it is one of the most important operational water quality parameters. Careful attention top $\mathrm{pH}$ control is necessary at all stages of water treatment to ensure satisfactory water clarification and disinfection. For effective disinfection with chlorine, the $\mathrm{pH}$ should preferable be less than 8; however, lower $\mathrm{pH}$ water is likely to be corrosive. The $\mathrm{pH}$ of the water entering the distribution system must be controlled to minimize the corrosion of water mains and pipes in household water systems. Alkalinity and calcium management also contribute to the stability of water and control its aggressiveness top pipe and appliance. Failure to minimize corrosion can result in the contamination of drinking water and in adverse effects on its taste and appearance (30).

In this study, although total organic substance was detected in $47 \%$ well and $39 \%$ tap water, ammonia did not detect in any of samples analyzed. The reason may be explained by its oxidation to nitrate and nitrite (28).

In most countries, nitrate levels in drinking-water derived from surface water do not exceed $10 \mathrm{mg} / 1$ (10). McLay et al. (18) reported that nine percent of sites surveyed had groundwater $\mathrm{NO}_{3}-\mathrm{N}$ concentrations exceeding maximum allowable concentrations of 11.3 ppm recommended by the World Health Organization for potable drinking water. Over half $(56 \%)$ of the sites had concentrations that exceeded $3 \mathrm{ppm}$, indicating effects of human activities on the groundwater. Babiker et al. (6) reported that $90 \%$ of water samples showed nitrate concentrations above $\left(3 \mathrm{mg} / \mathrm{N} \mathrm{NO}_{3}{ }^{-}\right)$the human affected value, while more than $30 \%$ have exceeded the maximum acceptable level $\left(44 \mathrm{mg} / \mathrm{NO}_{3}{ }^{-}\right)$according to Japan regulations. Oren et al. (20) showed that intensive irrigation and fertilization in the arid environment of Arava Valley significantly affects the quantity and quality of groundwater recharge. Low irrigation efficiency of about $50 \%$ contributes approximately 3.5-4 million $\mathrm{m}^{3}$ years to the hydrological system. During the research period, the natural recharge from floods was found to be negligible in relative to irrigation water. The nitrate concentrations in a local shallow groundwater lens range between 100 and $300 \mathrm{mg} / \mathrm{l}$ and in the upper subaquifer are over $50 \mathrm{mg} / \mathrm{l}$. A major source of nitrate is fertilizer $\mathrm{N}$ in the excess irrigation water. Reid et al. (23) reported that, the quality of private water supplies within Aberdeenshire sampled between 1992 and 1998, the individual failure rate was $15 \%$ for nitrate. 
The nitrate and nitrite contents of drinking and well water are also reported in several parts of the Turkey (21, 31,32 ). For instance, $20 \%$ of analyzed drinking water samples contained $50-100 \mathrm{ppm}$ nitrate, $7.5 \%$ of samples was over $100 \mathrm{ppm}$ nitrate in Bursa province reported (32). Özdemir et al. (21) reported that the nitrate levels in well water was 10.37-874.08 ppm, nitrite levels was 0$4.83 \mathrm{ppm}$, in Afyon. As a result of these studies, nitrate and nitrite levels of tap and well water samples were high like this study results. Generally, excessive amount of nitrate and nitrite in water is likely to be due to a combination of local and regional scale factors. It can be explained by (i) heavy rainfall during winter (ii) the sandy nature of the major soil of area (ii) shallow, polluted groundwater in many agriculture fields, and (iv) poor agricultural management, such as poor irrigation models and lack of good decision-making regarding the precise date of nitrogen fertilizer input and its quantity (23).

In conclusion, the indicator organisms of choice for fecal pollution should be $E$. coli. Thermotolerant coliforms can be used as an alternative to the test for $E$. coli in many circumstances. Pathogens more resistant to conventional environmental conditions or treatment technologies may be present in treated drinking-water in the absence of $E$. coli. Therefore verification may require analysis of a range of organisms, such as intestinal enterococci, Clostridium perfringens and bacteriophages. In addition, the total viable bacteria may be yield useful information about water quality and may provide supporting data on the significance of coliform test results. Another result from the present study clearly shows that nitrate and nitrite levels are elevated above health-based standards. The importance of a safe and reliable source of drinking water is beyond question.

\section{Acknowledgement}

This Project received financial support from Afyon Kocatepe University Scientific Research Project Commission (Research grant: 022-VF-17), Afyonkarahisar, Turkey.

\section{References}

1. American Public Health Association (APHA) (1976): Compendium of Methods for the Microbiological Examination of Foods. A.P.H.A. Inc. Washington D.C.

2. American Water Works Association (AWWA) (1999): Water quality and treatment, $5^{\text {th }}$ ed. New York: McGrawHill.

3. Anonim (1997): İçme Sulart Tebliği. 23172 Sayılı Resmi Gazete.

4. Anonim (2005): Sular-İnsani tüketim amaçlı sular (Water intended for human consumption). TS 266.
5. Association of Official Analytical Chemists (AOAC) (1995): Bacteriological Analytical Manual. $8^{\text {th }}$ Ed. AOAC. Washington DC.

6. Babiker IS, Mohamed MAA, Terao H, Kato K, Ohta K (2004): Assessment of groundwater contamination by nitrate leaching from intensive vegetable cultivation using geographical information system. Environ Int, 29, 10091017.

7. Baumgart J (1986): Mikrobiologische Untersuchung von Lebensmitteln. B. Behr's Verlag,

8. Center of Diseases Control (CDC) (2004): Surveillance data from public spa inspections-United States, May-September 2002. MMWR, 53, 553-555.

9. Cohn PD, Cox M, Berger PS (1999): Health and aesthetic aspects of water quality. Chapter 2. In: RD. Letterman Eds. Water Quality and Treatment, McGrawHill, Inc, New York.

10. ECETOC (1988): Nitrate and drinking water. Brussels, European Chemical Industry Ecology and Toxicology Centre (Technical Report No. 27).

11. European Union Council (EUC) (1980): Council directive relating to the quality of water intended for human consumption. (80/778/EEC). http://www.italo corotondo.it/tequila/module4/legislation/drink_water_direc tive_80.htm 15.12.2005

12. Food and Drug Administration (FDA) (1995): Escherichia coli and Coliform Bacteria, Chapter 4. In: Bacteriological Analytical Manual, $8^{\text {th }}$ ed. AOAC International.

13. Giannoulis N, Maipa V, Konstantinou I, Albanis T, Dimoliatis I (2005): Microbiological risk assessment of Agios Georgios source supplies in Northwestern Greece based on faecal coliforms determination and sanitary inspection survey. Chemosphere, 58, 1269-1276. GmbH\&Co., Berlin und Hamburg.

14. Hasde M, Oğur R, Tekbaș ÖF (2002): Ankara il merkezinde bulunan askeri birliklerdeki kuyu sularının polimeraz zincir reaksiyon sistemi ile mikrobiyolojik analizlerinin yapılması. Gülhane Tip Der, 44, 373-377.

15. Johnson CJ, Bonrod PA, Dosch TI, Kilness AW, Senger KA, Busch DC, Meyer MR (1987) Fatal outcome of methemoglobinemia in an infant. J Am Med Ass, 257, 2796-2807.

16. Mahler BJ, Personne JC, Lods GF, Drogue C (2000): Transport of free and particulate-associated bacteria in karst. J Hyd, 238,179-193.

17. Marsh TJ (1980): Towards a nitrate balance for England and Wales. Water Serv October, 601-606.

18. McLay CDA, Dragten R, Sparling G, Selvarajah N (2001): Predicting groundwater nitrate concentrations in region of mixed agricultural land use: a comparison of three approaches. Environ Pollut, 115, 191-204.

19. Nolan BT (2001): Relating nitrogen sources and aquifer susceptibility to nitrate in shallow groundwater's of the United States. Ground Water, 39, 290-299.

20. Oren O, Yechieli Y, Böhlke JK, Dody A (2004): Contamination of groundwater under cultivated fields in an arid environment central Arava Valley, Israel. J Hyd, 290, 312-328. 
21. Özdemir M, Yavuz H, İnce S (2004): Afyon Bölgesi kuyu sularında nitrat ve nitrit düzeylerinin belirlenmesi. Ankara Üniv Vet Fak Derg, 51, 25-28.

22. Payment P, Richardson L, Siemiatycki J, Dewar R, Edwardes M, Franco E (1991): A randomized trial to evaluate the risk of gastrointestinal disease due to consumption of drinking water meeting current microbiological standards. AJPH, 81, 703-708.

23. Reid DC, Edwards AC, Cooper D, Wilson E, Mcgaw BA (2003): The quality of drinking water from private water supplies in Aberdeenshire, UK. Water Res, 37, 245254.

24. Spalding RF, Exner ME (1993): Occurrence of nitrate in ground-water a review. J Environ Quality, 22, 392-402.

25. Stahr HM (1991): Analytical methods in Toxicology. 1519. John Wiley\&Sons, Inc.,New York.

26. Thatcher FS, Clark DS (1978): Microorganisms in Foods (2nd edition), University of Toronto Pres, TorontoBuffalo, London.

27. US Environmental Protection Agency (US EPA) (2006): Ground water \& drinking water. Consumer Fact sheet on: Nitrates/Nitrites. http://www.epa.gov/safewater/dwh/c-ioc/ nitrates.html, 03.01.2006

28. Van Duijvenboden W, Matthijen AJCM (1989): Integrated criteria document nitrate. Bilthoven, Rijksintituut voor de Volsksgezondheid en Milieuhygiene National Institute of Public Health and Environmental Protection (RIVM Report No. 758473012).
29. Vassiliadis P, Trichopoulos D, Pateraki E, Papaiconomou N (1978). Isolation of Salmonella from minced meat by the use of a new procedure of enrichment, Zentr Bakteriol [Orig B], 166, 81-86.

30. World Health Organisation (WHO) (2004): Guidelines for drinking-water quality. Third Edition, Volume 1 Recommendations, Geneva. Printed in China by Sun Fung.

31. Yavuz H, Kaya S, Akar F (1993): Hayvanlarda içme suyu olarak kullanilan kuyu sularında nitrat ve nitrit düzeyleri. Ankara Üniv Vet Fak Derg, 40, 16-22.

32. Yılmaz O, Sonal S, Ceylan S (1993): Bursa yöresi tavuk çitliklerinin içme sularındaki nitrat düzeyleri. Uludağ Üniv Vet Fak Derg, 12, 20-23.

Geliş tarihi: 05.01.2006 / Kabul tarihi: 28.07.2006
Address for correspondance:
Yard.Doç.Dr. Mehmet Özdemir A.K.Ü. Veteriner Fakültesi
Farmakoloji ve Toksikoloji Anabilim Dall, Ahmet Necdet Sezer Kampusü, 03200, Afyonkarahisar. e-mail:mozdemir@aku.edu.tr 